\title{
Prevalence of Antibodies to Toxoplasma gondii in Cats, Dogs and Horses in Sweden
}

\author{
By Arvid Uggla, Susanne Mattson and Nils Juntti \\ Department of Cattle and Sheep Diseases, Faculty of Veterinary Medicine, \\ Swedish University of Agricultural Sciences, and the Department of Virology, \\ National Veterinary Institute, Uppsala, Sweden.
}

\begin{abstract}
Uggla, A., S. Mattson and N. Juntti: Prevalence of antibodies to Toxoplasma gondii in cats, dogs and horses in Sweden. Acta vet. scand. 1990, 31, 219-222. Samples of serum or plasma taken during 1986 and 1987 from 244 pet cats, 303 dogs and 219 horses, randomly selected among animals referred to the Animal Clinics of the Swedish University of Agricultural Sciences, were screened by enzymelinked immunosorbent assay (ELISA) for antibodies to Toxoplasma gondii. $42 \%$ of cats, $23 \%$ of dogs and $1 \%$ of horses examined were found seropositive.
\end{abstract}

\section{Introduction}

parasitic infection; protozoa; zoonosis; enzyme immunoassay.
Toxoplasma gondii is a ubiquitous coccidian parasite having felines as final hosts and an exceptionally wide range of warmblooded animals, including man, as possible intermediate hosts (Dubey 1986). In Sweden, the infection is common in man (Ljungström et al. 1989), in meatproducing animals as pigs (Hansen et al. 1965, Uggla \& Hjort 1984) and sheep (Uggla \& Hjort 1984, Lundén et al. 1989), and in game such as hares (Gustafsson et al. 1988). However, the seroprevalence of $T$. gondii in the feline final host as well as in dogs and horses in Sweden has not previously been reported.

\section{Materials and methods}

\section{Animals}

The study comprises a random selection of 244 cats, 303 dogs and 219 horses referred during 1986 and 1987 to the Animal Clinics of the Veterinary Faculty, Swedish University of Agricultural Sciences, Uppsala, Sweden. The animals were brought to the clinics for a variety of reasons, including various infectious as well as non-infectious diseases, traumatic injuries, lameness, and health cer- tification. No case of suspected or clinically verified toxoplasmosis was included in the study. Cats and dogs were pet animals of different ages and breeds and originating predominantly from the Uppsala area in Central Sweden. Horses were adult trotters or riding horses from Central Sweden. Venous blood was withdrawn from cats and dogs in tubes with or without anticoagulants as heparin or EDTA. Blood from horses was withdrawn in tubes without anticoagulant. Serum or plasma was prepared and then stored at $-20^{\circ} \mathrm{C}$ until analysed for Toxoplasma antibodies by enzyme-linked immunosorbent assay (ELISA).

\section{Toxoplasma ELISA}

Cat sera or plasma and horse sera were diluted 1:400 and dog sera or plasma 1:100, in PBS with $0.2 \%$ Tween 20 (PBS-T) and analysed in a conventional Toxoplasma ELISA system carried out principally as described by Voller et al. (1976). Microtitre plates (Immunoplate II, Nunc, Roskilde, Denmark) were coated overnight at $+4^{\circ} \mathrm{C}$ with a soluble antigen preparation consisting of a 
sonicated extract of purified, repeatedly freeze-thawed Toxoplasma tachyzoites (National Bacteriological Laboratory, Stockholm, Sweden). The antigen concentration was $0.34 \mu \mathrm{g}$ protein per well in $100 \mu \mathrm{l}$ of 0.1 $\mathrm{mol} / \mathrm{l}$ carbonate buffer, $\mathrm{pH}$ 9.6. After washing in PBS-T, $100 \mu$ l of diluted serum or plasma was added in duplicate to the wells and the plates incubated at $+37^{\circ} \mathrm{C}$ for $1 \mathrm{~h}$. After repeated washing, $100 \mu \mathrm{l}$ of a horseradish peroxidase (HPR) conjugated anti-cat immunoglobulin (Ig) $\mathrm{G}$ preparation (National Veterinary Institute, Uppsala, Sweden), diluted 1:500 (for cat sera), protein A preparation (Pharmacia, Uppsala, Sweden), diluted 1:1000 (for horse sera), or monoclonal anti-dog IgG preparation (National Veterinary Institute), diluted 1:1000 (for dog sera), in PBS-T with $2.5 \%$ swine serum, was added and incubation performed for $1 \mathrm{~h}$ at $+37^{\circ} \mathrm{C}$. After a final wash, $100 \mu \mathrm{l}$ of enzyme substrate hydrogene peroxide and tetramethyl benzidine (Sigma, St. Louis, Mo., USA), was added to each well and left to react at $+37^{\circ} \mathrm{C}$ for $1 \mathrm{~h}$, after which the reaction was stopped by adding $50 \mu \mathrm{l}$ of $2 \mathrm{~mol} / \mathrm{l}$ sulphuric acid. The optical density (OD) values were read at $450 \mathrm{~nm}$ using a Titertec Multiscan spectrophotometer (Flow Laboratories, Irvine, Scotland). Samples showing OD values exceeding $0.20,0.30$ or 0.25 for cats, horses and dogs respectively, were considered as positive. Positive and negative controls were included on each plate. Cat and horse controls were pre- and post-inoculation sera from experimentally infected animals, and dog controls were sera found positive and negative, respectively, at screening in the indirect fluorescent antibody test (Uggla \& Hjort 1984). From several individual cats and dogs where both serum and the corresponding plasma sample were available, they were both included in the assay for comparison of OD values.

\section{Results}

$42 \%$ (101) of the 241 feline samples tested had $O D$ values exceeding 0.20 (mean 0.91 \pm S.D. 0.30). Mean values for negative samples were $0.06 \pm$ S.D. 0.04 .

$23 \%(69)$ of the 302 canine samples tested had OD values exceeding 0.25 (mean 0.85 \pm S.D. 0.39). The 238 negative samples had a mean of $0.06 \pm$ S.D. 0.05 .

Two out of the 219 equine sera tested, comprising $1 \%$ of the material, showed OD values exceeding 0.30 (0.40 and 1.02 , respectively). The 217 negative sera had a mean OD value of $0.11 \pm$ S.D. 0.04 .

There were no noticeable difference in OD values between serum and corresponding plasma samples from either dogs or cats.

\section{Discussion}

The present study is the first to describe the prevalence of Toxoplasma infection in populations of cats, dogs and horses in Sweden. The prevalence rate of Toxoplasma infection in pet cats is of particular interest since felines are the final hosts of $T$. gondii capable of spreading the infection by oocysts to other animals and man (Dubey 1986).

Infected prey or raw meat or organs given as feed are the main sources for cats to contract a $T$. gondii infection. After a prepatent period of 3-25 days depending on the source of infection, cats will, generally without showing any clinical signs of the infection, shed oocysts for 7-20 days and then normally be immune against reinfection and reshedding for the rest of their lives (Dubey 1986). The population tested in this survey comprised pet cats, many of which are allowed to hunt wild prey outdoors. Our results show that a substantial proportion of pet cats from the actual part of Sweden have not experienced a Toxoplasma infection and may therefore be potential excreters of oocysts after ingesting viable $T$. gondii in prey or feed. The 
seropositivity rate of $42 \%$ as observed in cats in this study can be compared to $63 \%$ found in Denmark (Work 1969) and $24 \%$ in Norway (Kapperud 1978).

Clinical toxoplasmosis in dogs is rare and has generally been associated with concomitant infection with distemper virus, which is known to produce immunosuppression (Dubey et al. 1989). Not more than 30 cases of toxoplasmosis-like illness were observed among 11,000 dogs necropsied at the Angell Memorial Animal Hospital in Boston, USA, during 1948-1987. In a retrospective study using immunohistochemical techniques (Uggla et al. 1987) only 13 of these cases were proven to be caused by $T$. gondii (Dubey et al. 1989). Recently, a new Toxoplasma-like parasite in dogs, Neospora caninum, was described (Bjerkås \& Presthus 1988, Dubey et al. 1988). It is obvious that this organism has previously been frequently mistaken for $T$. gondii when found at post mortem examinations (Dubey et al. 1988). $N$. caninum is however antigenically distinct from $T$. gondii as judged by immunohistochemical reactions, and a possible presence of Neospora antibodies in samples tested in serological surveys for $T$. gondii should therefore not have influenced the results obtained.

In the present study, $23 \%$ of dogs tested were found to have antibodies to $T$. gondii. Earlier studies in dogs in other Scandinavian countries revealed seropositivity rates of $45 \%$ in Norway (Borgen \& Berg 1957) and $43 \%$ in Denmark (Work 1969). For comparison it can be mentioned that a seroprevalence of $18 \%$ was recently recorded in women in Central Sweden (Ljungström et al. 1989).

Equines are regarded as being resistant to $T$. gondii infection, and, apart from a transient fever in some cases, clinical symptoms were not observed at experimental in- fections (Dubey 1985). Furthermore, exceptionally few cases of clinical toxoplasmosis in equines have been reported from the field, and it is believed that some earlier observations of equine toxoplasmosis might have been due to infection with a morphologically related organism, possibly a Sarcocystis species, causing the so called equine protozoal encephalomyelitis (Simpson \& Mayhew 1980).

As compared to other domestic animals, relatively few serological screenings for Toxoplasma antibodies have been performed in equines. In the present study only $1 \%$ of animals tested were found seropositive. The figures can be compared to $20 \%$ found in the USA (Riemann et al. 1975) and $25 \%$ in Brazil (Costa et al. 1986). Al-Khalidi \& Dubey (1979) isolated $T$. gondii from edible tissue of 7 out of 500 horses slaughtered in Ohio, USA, and von den Drisch (1987) from 2 out of 108 horses in Germany. It has been demonstrated that $T$. gondii can be isolated from tissues of infected horses as long as 16 months after inoculation (Dubey 1985). Thus, despite a low prevalence rate of $T$. gondii as observed in this study, uncooked or undercooked horsemeat from Sweden must be regarded as a potential source of infection in humans as well as other carnivores.

\section{Acknowledgements}

The study was supported by the Swedish Council for Forestry and Agricultural Research. We also wish to thank Dr. J. P. Dubey for kindly providing equine control sera, and Mrs. M. Hjort for technical assistance.

\section{References}

Al-Khalidi $N W$, Dubey JP: Prevalence of Toxoplasma gondii infection in horses. J. Parasitol. 1979, 65, 331-334.

Bjerkås I, Presthus J: Immunohistochemical and ultrastructural characteristics of a cyst-for- 
ming sporozon associated with encephalomyelitis and myositis in dogs. Acta pathol. microbiol. immunol. scand. 1988, 96, 445-454.

Borgen PHF, Berg OA: Toxoplasma dye test in dogs in Norway. Acta path. microbiol. scand. 1957, 41, 353-357.

Costa AJ, Ishizuka MM, Marques LC, Vidotto $O$, Rocha UF, Ikeda A: Toxoplasmosis frequency in equines from the north region of Sao Paulo state, Brazil. Ars Veterinaria 1986, 2, 75-79. von den Drisch $H$ : Untersuchungen über die Häufigkeit von Toxoplasma gondii und anderen auf die Katze übertragbaren Parasiten in wildlebenden Nagern und in Pferdefleisch. (Investigation of the frequency of Toxoplasma gondii and other parasites in wild living rhodents and horse meat that are transmissible to cats). Dissertation, Tierärztliche Hochschule, Hannover, F. R. Germany 1987, 1-98.

Dubey JP: Persistence of encysted Toxoplasma gondii in tissues of equids fed oocysts. Amer. J. vet. Res. 1985, 46, 1753-1754.

Dubey JP: Toxoplasmosis in cats. Feline Pract. 1986, 16, 12-26, 44-45.

Dubey JP, Carpenter JL, Speer CA, Topper MJ, Uggla $A$ : Newly recognized fatal protozoan disease of dogs. J. Amer. vet. med. Assoc. 1988, 192, 1269-1285.

Dubey JP, Carpenter JL, Topper MJ, Uggla A: Fatal toxoplasmosis in dogs. J. Amer. anim. Hosp. assoc. 1989, 25, 659-664.

Gustafsson K, Uggla A, Svensson T, Sjöland L: Detection of Toxoplasma gondii in liver tissue sections from brown hares (Lepus europaeus $P$.) and mountain hares (L.timidus $L$.) using the peroxidase-anti-peroxidase (PAP) technique as a complement to conventional histopathology. J. vet. Med. B, 1988, 35, 402-407.

Hansen $H-J$, Huldt $G$, Tafvelin B: On porcine toxoplasmosis in Sweden. Nord. Vet.-Med. 1977, 29, 381-385.

Kapperud $G$ : Survey for toxoplasmosis in wild and domestic animals from Norway and Sweden. J. Wildl. Dis. 1978, 14, 157-162.
Ljungström I, Gille E, Linder E: The seroprevalence of toxoplasmosis in Sweden. Proc. XIV Scand. Symp. Parasitol., Elsinore, Denmark 1989, p. 36.

Lundén A, Alenius $S$, Carlson U, Uggla A: Toxoplasma gondii in Swedish sheep: Seroprevalence and incidence of infection during pregnancy. Proc. XIV Scand. Symp. Parasitol., Elsinore, Denmark 1989, p. 52.

Riemann HP, Smith AT, Stormont C, Ruppanner $R$, Behymer $D E$ et al: Equine toxoplasmosis. A survey for antibodies to Toxoplasma gondii in horses. Amer. J. vet. Res. 1975, 36, 17971800.

Simpson CF, Mayhew IG: Evidence for Sarcocystis as the etiological agent for equine protozoal myeloencephalitis. J. Protozool. 1980, 27, 288-292.

Uggla A, Hjort M: A serological study on the prevalence of Toxoplasma gondii in meatproducing animals in Sweden. Acta vet. scand. 1984, 25, 567-576.

Uggla A, Sjöland L, Dubey JP: Immunohistochemical diagnosis of toxoplasmosis in fetuses and fetal membranes of sheep. Amer. J. vet. Res. 1987, 48, 348-351.

Voller A, Bidwell DE, Bartlett A, Fleck DG, Perkins $M$, Oladehin $B$ : A microplate enzymeimmunoassay for Toxoplasma antibody. J. clin. Pathol. 1976, 29, 150-153.

Work $K$ : The incidence of Toxoplasma antibodies among dogs and cats in Denmark. Acta pathol. microbiol. scand. 1969, 75, 447-456.

\section{Sammanfattning}

Förekomst av antikroppar mot Toxoplasma gondii hot katter, hundar och hästar $i$ Sverige. Serum eller plasma från 244 tamkatter, 303 hundar och 219 sporthästar som provtagits vid djurklinikerna vid Sveriges lantbruksuniversitet i Uppsala under 1986 och 1987 testades med ELISA för antikroppar mot Toxoplasma gondii. Prevalensen seropositiva djur befanns vara $42 \%$, $23 \%$ och $1 \%$, respektive.

(Received September 7, 1989; accepted September 29, 1989).

Reprints may be requested from: Arvid Uggla, Department of Cattle and Sheep Diseases, Swedish University of Agricultural Sciences, P. O. Box 7019, S-750 07 Uppsala, Sweden. 